\title{
Terminalia ivorensis A. Chev. Ethanolic Stem Bark Extract Protects Against Gentamicin-Induced Renal and Hepatic Damage in Rats
}

\author{
Charles Ansah*, Aliu Moomin, Kwesi Mensah Boadu \\ Department of Pharmacology, Faculty of Pharmacy and Pharmaceutical Sciences, College of Health Sciences, Kwame Nkrumah University of Science and \\ Technology, Kumasi, Ghana.
}

\section{ARTICLE INFO \\ Article history: \\ Received on: 13/11/2015 \\ Revised on: 19/12/2015 \\ Accepted on: 26/02/2016 \\ Available online: 30/04/2016}

Key words:

Renal damage, hepatic

damage, gentamicin,

Terminalia ivorensis.

\begin{abstract}
The aim of present study was to investigate the possible protective effects of an ethanolic stem bark extract of Terminalia ivorensis on gentamicin - induced nephrotoxicity and hepatotoxicity in male Sprague-Dawley rats. Groups of animals received either gentamicin alone or in combination with $100,300 \mathrm{or} 1000 \mathrm{mg} / \mathrm{kg}$ of extract for a period of 14 days. On the $15^{\text {th }}$ day, the modulatory effect of Terminalia ivorensis was examined by assessing biochemical and renal markers of hepatic and renal damage. Markers of oxidative injury including reduced glutathione, superoxide dismutase, catalase and lipid peroxidation were assessed. Histology of the kidneys and the liver were also processed for analysis. The extract at a dose of $100-1000 \mathrm{mg} / \mathrm{kg}$ significantly reduced elevations in creatinine, urea and serum enzymes evokedby gentamicin. Additionally, the low levels of reduced glutathione and the antioxidant enzymes from the gentamicin treatment were significantly improved in the extract-treated animals. The results correlated well with the histopathological findings as the extract reversed the severe architectural distortions of the kidneys and liver caused by gentamicin. We conclude from the study that, the ethanolic stem bark extract of Terminalia ivorensis protects the liver and the kidneys against gentamicininduced renal and hepatic damage.
\end{abstract}

\section{INTRODUCTION}

Nephrotoxicity is a common and serious side effect of conventional medications (Rajitha et al., 2013). Available records indicate that 27 million people have chronic kidney disease with a rise of $30 \%$ over the past decade (Coresh et al., 2007). Renal insufficiency is observed in nearly $2 \%$ cases of acetaminophen over dosage and the occurrence of renal dysfunction from aminoglycosides especially gentamicin increased from $3 \%$ in 1969 to 10-20\% in the past few years (Eslami et al., 2011; Rajitha et al., 2013). Renal injury is also caused by various compounds including potassium dichromate (Pedraza-Chaverri, 2008) used in the metallurgical, chrome plating, paint, leather tanning, photographic, textile manufacturing and wood preservation industries. The nephrotoxic effect of the aminoglycosides has been strongly linked to the preferential accumulation in renal cortex (Luft and Kleit, 1974). Another common and relevant adverse effect of drug therapy is hepatotoxicity, which accounts

\footnotetext{
* Corresponding Author

Charles Ansah, Department of Pharmacology, Faculty of Pharmacy and Pharmaceutical Sciences, College of Health Sciences, Kwame Nkrumah University of Science and Technology, Kumasi, Ghana.

Email: cansah.pharm[at]knust.edu.gh
}

for $5 \%$ of all hospitalized cases and $75 \%$ of adverse reactions resulting in death (Sivakrishnan and Kottaimuthu, 2013; Aashish et al., 2012). Consequently, hepatic injury has been a common cause of drug withdrawal from the market (Jaeschke et al., 2002). The integrity of the kidney and the liver are compromised in injury. This could exacerbate the conditions since these are the main organs for drug metabolism and consequent elimination from the body. Available drugs for the management of renal and hepatic injury are rather limited. Medicinal plants have been used for the cure of several human diseases and are gaining more acceptability due to less toxicity and high efficacy (Aslam et al., 2013). Among the medicinal plants used for the treatment of various diseases is Terminalia ivorensis. Terminalia ivorensis A. Chev (Combretaceae) is a tree located in the tropical and sub-tropical regions of the world (Burkill, 1985). The plant has several traditional uses. For example, it has been used to treat ulcers, cuts, sores, wounds, general body pains, hemorrhoids, malaria, yellow fever and for the induction of diuresis (Quattara et al., 2013; Akinyemi et al., 2006; Etukudo, 2003; Burkill, 1985). Gentamicin is used widely in the treatment of gram-negative infections. Gentamicin is known to be potentially nephrotoxic at levels marginally above the therapeutic dose (Pedraza et al., 2000; Conlon et al., 1999). 
Renal damage induced by the aminoglycosides can be accompanied by liver injury (Martines et al., 1988). Considering the effectiveness of gentamicin in the management of gramnegative infections albeit the potential to evoke renal and hepatic damage, a plant drug administered concomitantly to modulate the risk of nephrotoxicity and hepatotoxicity would be worthwhile. We evaluated Terminalia ivorensis in the present study against gentamicin-induced nephrotoxicity and hepatotoxicity on the basis of its traditional use on the urinary system and the reported wide traditional uses of the plant.

\section{MATERIALS AND METHODS}

\section{Preparation of plant material}

Stem bark of Terminalia ivorensis was collected from Asakraka Kwahu in the Eastern region (Ghana)in September 2014 and authenticated at the Department of Pharmacognosy, Faculty of Pharmacy and Pharmaceutical Sciences KNUST Kumasi Ghana by Dr. Kofi Annan. A voucher herbarium specimen number FP/095/10 was prepared and deposited in the department's herbarium. The harvested stem bark was washed, air dried for 14 days and ground with a laboratory blender. It was weighed and extracted with $70 \%$ ethanol. The sample was oven dried at $55^{\circ}$ Cand the yield obtained was $24.3 \% \mathrm{w} / \mathrm{w}$, referred in this paper as TIE. TIE was stored in a refrigerator until use. The extract was freshly dissolved in distilled water, which was used as vehicle for the control group. Administration to the animals was oral by gavage and the concentrations were prepared such that no animal received more than $1.0 \mathrm{~mL} / \mathrm{kg}$ body weight.

\section{Animals}

Male Sprague - Dawley rats $(180-240 \mathrm{~g})$ were obtained from the Animal house of the Department of Pharmacology, Kwame Nkrumah University of Science and Technology (KNUST), Kumasi, Ghana. The animals were acclimatized for one week with free access to laboratory feed and water ad libitum. All the animals were housed in aluminium laboratory cages $(34 \mathrm{x} 47 \mathrm{x}$ $18 \mathrm{~cm}$ ) with fine wood shavings as bedding. Animals were humanely treated and all experiments were approved by the Faculty of Pharmacy and Pharmaceutical Sciences ethics committee.

\section{Effect of extract on gentamicin- induced nephrotoxicity and hepatotoxicity}

The method used was as described by Qadir et al., (2011). Briefly, thirty (30) male Sprague - Dawley rats (180 - 240 g) were weighed, put into five groups $(n=6)$ and left to acclimatize to their new environment for one week with adequate fresh water and feed. Animals were grouped and drugs administered as follows:

- Group I (control): received distilled water (1 $\mathrm{mL} / \mathrm{kg} /$ day p.o) for 14 days.

- Group II received gentamicin (80 mg/kg/day i.p.) for 14 days.
- Group III: received extract (100 mg/kg/dayp.o ) + gentamicin $(80 \mathrm{mg} / \mathrm{kg} /$ day i.p.) for 14 days.

- Group IV: received extract (300 mg/kg/day p.o) + gentamicin (80mg/kg/day i.p.) for 14 days.

- Group V: received extract $(1000 \mathrm{mg} / \mathrm{kg} / \mathrm{day}$ p.o $)+$ gentamicin (80mg/kg/day i.p.) for 14 days.

Treatment of animals with the extract for groups III, IV and V started 3 days prior to the commencement of the study. Injection of gentamicin was done at 10:00 hours to minimize the circadian variation in nephrotoxicity. On day 14, all animals were put in metabolic cages for collection of 24 - hour urine sample. On the $15^{\text {th }}$ day, all animals were weighed and blood samples collected for estimation of serum electrolytes, blood urea and creatinine levels as well as liver biomarkers. All animals were then sacrificed and their kidneys and livers removed, washed with normal saline and weighed. The right kidneys and livers were preserved for histopathological studies while left kidneys were used for preparation of post - mitochondrial supernatant.

\section{Estimation of renal and liver biomarkers}

Blood samples were centrifuged at 5000 r.p.m for 10 minutes to obtain sera which were used for the estimation of the kidney and liver biochemical markers. Urea and creatinine were determined with Biotecnica BT 3000 Targa chemistry analyzer (Diamond Diagnostics, USA). Measurement of sodium, potassium and chloride were done with Flexor Junior Auto analyzer. Liver biomarkers were also measured with Biotecnica BT 3000 Targa chemistry analyzer (Diamond Diagnostics, USA).

\section{Preparation of tissue homogenate}

Left kidneys were quickly removed, cleaned and immediately stored in ice-cold saline $(0.85 \%$ sodium chloride $)$. Kidneys were homogenized in phosphate buffer $(0.1 \mathrm{M}, \mathrm{pH} 7.4)$ containing $\mathrm{KCl}(1.17 \%)$ at $4{ }^{\circ} \mathrm{C}$ with Potter-Elvehjem homogenizer (Ultra-Turrax T25, Janke \& Kunkel IKALabortechnik, Germany). The homogenate was filtered with a clean handkerchief and centrifuged with Hettich-zentrifugen (Micro 220R, Germany) at $800 \mathrm{X}$ g for 5 minutes at $4{ }^{\circ} \mathrm{C}$. The supernatant was again centrifuged at 5000 r.p.m for 30 minutes at $4{ }^{\circ} \mathrm{C}$ to obtain the tissue homogenate which was used as the enzyme source for the biochemical estimations. All the experiments were performed within 24 hours of animal sacrifice -

\section{Estimation of markers of oxidative stress}

The method of Ellman, (1959) was used for estimation of reduced glutathione. Superoxide dismutase levels were measured as described by Sun et al., (1988) and catalase activity was assessed using a method of Sinha, (1972). Lipid peroxidation was examined in terms of malondialdehyde (MDA) formed as described by Ohkawa et al., (1979) and the amount of myeloperoxidase (MPO) formed was evaluated using the method of Senoglu et al., (2009). 
Table 1: Effect of TIE and Gentamicin on serum creatinine and urea

\begin{tabular}{lll}
\hline Treatment group & Creatinine/ $\boldsymbol{\mu \text { mol} / \mathbf { L }}$ & Urea/ mmol/L \\
\hline Control: distilled $10 \mathrm{ml} / \mathrm{kg}$ & $33.10 \pm 1.77$ & $11.66 \pm 0.67$ \\
Gent $80 \mathrm{mg} / \mathrm{kg}$ & $102.70 \pm 11.75^{* * *}$ & $22.42 \pm 2.90^{* * * *}$ \\
TIE $100 \mathrm{mg} / \mathrm{kg}+$ Gent $80 \mathrm{mg} / \mathrm{kg}$ & $59.03 \pm 2.78^{* \mathrm{ttt}}$ & $16.36 \pm 0.99$ \\
TIE $300 \mathrm{mg} / \mathrm{kg}+$ Gent $80 \mathrm{mg} / \mathrm{kg}$ & $47.83 \pm 3.51^{\text {tt }}$ & $12.86 \pm 0.66^{\mathrm{ttt}}$ \\
TIE $1000 \mathrm{mg} / \mathrm{kg}+$ Gent $80 \mathrm{mg} / \mathrm{kg}$ & $53.48 \pm 5.74^{\mathrm{ttt}}$ & $13.21 \pm 0.82^{\mathrm{tt}}$ \\
\hline
\end{tabular}

All data are expressed as mean \pm S.E.M. $(\mathrm{n}=6),{ }^{*} \mathrm{p}<0.05,{ }^{* *} \mathrm{p}<0.01$ and $* * * \mathrm{p}<0.001$ as compared to the control group (one way ANOVA followed by Sidak's post hoc test). "tp $<0.01$ and ${ }^{t t t} p<0.001$ as compared to gentamicin group (one way ANOVA followed by Sidak's post hoc test).

Table 2: Effect of TIE and Gentamicin on serum sodium, potassium and chloride levels.

\begin{tabular}{llll}
\hline Treatment group & Sodium/ m/L & Potassium/ m/L & Chloride/ m/L \\
\hline Control: distilled $10 \mathrm{ml} / \mathrm{kg}$ & $115.3 \pm 2.45$ & $8.48 \pm 0.46$ & $78.33 \pm 1.61$ \\
Gent $80 \mathrm{mg} / \mathrm{kg}$ & $135.2 \pm 2.80^{* * *}$ & $16.40 \pm 0.50^{* * *}$ & $98.67 \pm 1.71^{* * *}$ \\
TIE $100 \mathrm{mg} / \mathrm{kg}+$ Gent $80 \mathrm{mg} / \mathrm{kg}$ & $136.7 \pm 1.43^{* * *}$ & $13.10 \pm 0.49^{* * * * t t}$ & $90.67 \pm 0.88^{* * * * t t}$ \\
TIE $300 \mathrm{mg} / \mathrm{kg}+$ Gent $80 \mathrm{mg} / \mathrm{kg}$ & $123.2 \pm 0.60^{\mathrm{tt}}$ & $11.00 \pm 0.33^{* * * t t}$ & $84.83 \pm 0.95^{* \mathrm{ttt}}$ \\
TIE $1000 \mathrm{mg} / \mathrm{kg}+$ Gent $80 \mathrm{mg} / \mathrm{kg}$ & $118.0 \pm 1.77^{\mathrm{ttt}}$ & $9.53 \pm 0.28^{\text {ttt }}$ & $80.67 \pm 0.76^{\mathrm{tt}}$ \\
\hline
\end{tabular}

All data are expressed as mean \pm S.E.M. $(\mathrm{n}=6),{ }^{*} \mathrm{p}<0.05, * * \mathrm{p}<0.01$ and $* * * \mathrm{p}<0.001$ when compared to the control group (one way ANOVA followed by Sidak's post hoc test). "t $p<0.01$ and ${ }^{\text {ttt }} \mathrm{p}<0.001$ when compared to gentamicin group (one way ANOVA followed by Sidak's post hoc test).

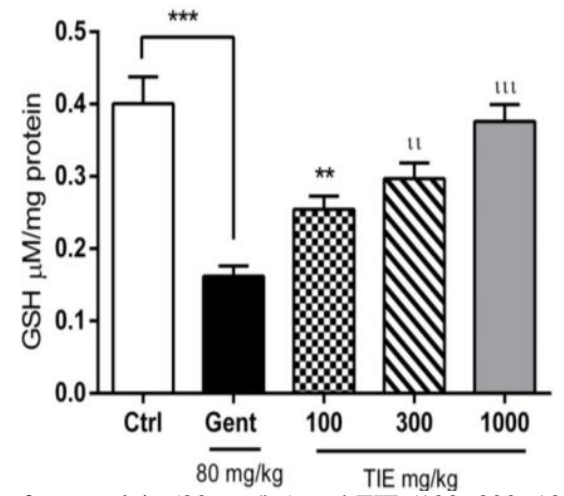

Fig. 1: Effect of gentamicin $(80 \mathrm{mg} / \mathrm{kg})$ and TIE $(100,300,1000 \mathrm{mg} / \mathrm{kg})$ on GSH levels. **p< 0.01 and $* * * p<0.001$ as compared to the control group (one way ANOVA followed by Sidak's post hoc test). "tp< 0.01 and ttp $\mathrm{p}$ 0.001 when compared to gentamicin group (one way ANOVA followed by Sidak's post hoc test).

\section{Histopathological analysis}

Immediately after sacrifice, right kidneys of rats were stored in neutral buffered formalin $(10 \%)$ for histological processing. Sections of the kidneys and livers were stained with hemotoxylin and eosin, and observed under a Leica DM 750 microscope (ICC50 HD, JosHansen, Germany) at magnifications of X 400 for kidneys and X100 for livers.

\section{Data analysis}

Data analysis was done with GraphPad Prism 6.0. All results were presented as mean \pm standard error of mean (SEM) and $(\mathrm{p}<0.05)$ was considered significant. Comparison within groups was done using One Way Analysis of Variance (ANOVA) followed by Sidak's multiple comparison tests.

\section{RESULTS}

\section{Effect of gentamicin and TIE on renal parameters and electrolytes}

Serum creatinine levels were significantly elevated in the gentamicin-only treated group $(\mathrm{p}<0.001)$ compared to the control, whereas significant decrease in creatinine $(p<0.001)$ was observed

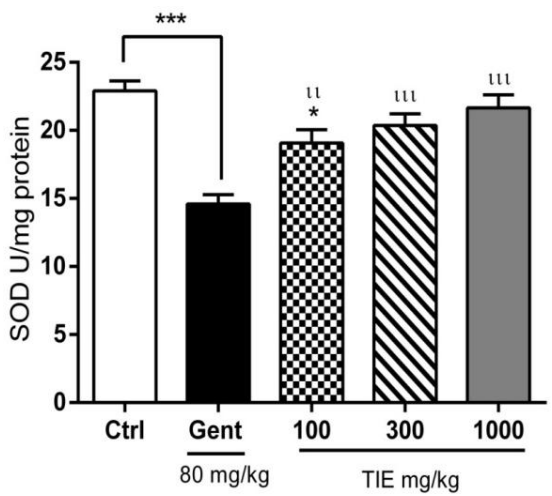

Fig. 2: Effect of gentamicin $(80 \mathrm{mg} / \mathrm{kg})$ and TIE $(100,300,1000 \mathrm{mg} / \mathrm{kg})$ on SOD levels. $* \mathrm{p}<0.05$ and $* * * \mathrm{p}<0.001$ as compared to the control group (one way ANOVA followed by Sidak's post hoc test). ${ }^{t t} p<0.01$ and ${ }^{t t t} p<0.001$ when compared to gentamicin group (one way ANOVA followed by Sidak's post hoc test).

in extract pre-treated groups when compared to the gentamicin group. Similarly, gentamicin significantly $(\mathrm{p}<0.001)$ increased the serum urea levels of rats when compared to the control. However, reduced serum urea levels were observed in animals pretreated with $300(\mathrm{p}<0.001)$ and $1000 \mathrm{mg} / \mathrm{kg}$ of extract $(\mathrm{p}<0.01)$ when compared to the gentamicin treated group (Table 1). Serum electrolytes (sodium, potassium and chloride) were significantly $(\mathrm{p}<0.001)$ increased in the gentamicin-only treated group. The group treated with $300 \mathrm{mg} / \mathrm{kg}$ TIE and gentamicin (80 $\mathrm{mg}$ ) caused significant reduction in sodium $(\mathrm{p}<0.01)$, potassium $(\mathrm{p}<0.001)$ and chloride levels $(\mathrm{p}<0.001)$. Similarly, combination treatment of $1000 \mathrm{mg} / \mathrm{kg} \mathrm{TIE}$ and gentamicin reduced the electrolytes significantly $(\mathrm{p}<0.001)$ to normal levels.

TIE $100 \mathrm{mg} / \mathrm{kg}$ with gentamicin decreased potassium $(\mathrm{p}<0.001)$ and chloride $(\mathrm{p}<0.01$ but not sodium levels (Table 2$)$.

\section{Effect of TIE and Gentamicin on antioxidant enzymes}

Gentamicin $(80 \mathrm{mg} / \mathrm{kg})$, significantly $(\mathrm{p}<0.001)$ decreased tissue GSH of rats compared to the control. Pretreatment with 300 and $1000 \mathrm{mg} / \mathrm{kg}$ TIE significantly $(\mathrm{p}<0.01 ; \mathrm{p}<0.001$ respectively) restored the GSH levels compared to the gentamicinonly treated group (Figure 1). The oxidative stress caused by the 
gentamicin treatment significantly $(\mathrm{p}<0.001)$ decreased kidney superoxide dismutase levels in treated animals compared to the control group. However, SOD increased significantly $(\mathrm{p}<0.01$; $\mathrm{p}<0.001$ and $\mathrm{p}<0.001)$ in animals that received $100 \mathrm{mg} / \mathrm{kg}, 300$ and $1000 \mathrm{mg} / \mathrm{kg}$ of extract respectively in combination with gentamicin (Figure 2). Gentamicin $(80 \mathrm{mg} / \mathrm{kg}$ ) reduced catalase significantly $(\mathrm{p}<0.001)$ compared to the control group. Animals that received gentamicin with extract at 300 and $1000 \mathrm{mg} / \mathrm{kg}$ significantly $(\mathrm{p}<0.001)$ improved catalase levels compared to the gentamicin-only group (Figure 3).

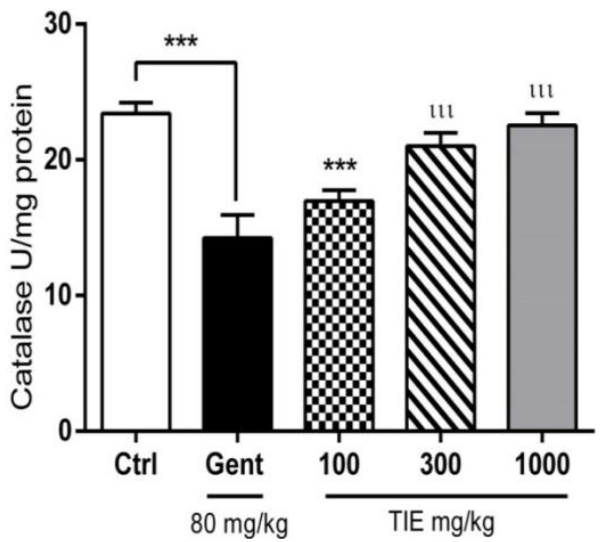

Fig. 3: Effect of gentamicin $(80 \mathrm{mg} / \mathrm{kg})$ and TIE $(100,300,1000 \mathrm{mg} / \mathrm{kg})$ on catalase levels. $* * * p<0.001$ as compared to the control group (one way NOVA followed by Sidak's post hoc test) and ttp $<0.001$ when compared to gentamicin group (one way ANOVA followed by Sidak's post hoc test).

\section{Effect of TIE and Gentamicin on lipid peroxidation}

Lipid peroxidation was measured in terms of the amount of malondialdehyde (MDA) produced. Induction of oxidative stress with gentamicin significantly increased the amount of MDA produced in the gentamicin-only treated group $(p<0.001)$ when compared to the control group. MDA formation was however significantly obliterated in animals treated with gentamicin and the extract at $100(\mathrm{p}<0.05), 300(\mathrm{p}<0.01)$ and $1000 \mathrm{mg} / \mathrm{kg}(\mathrm{p}<0.001)$ compared to the gentamicin-only group (Figure 4 ).

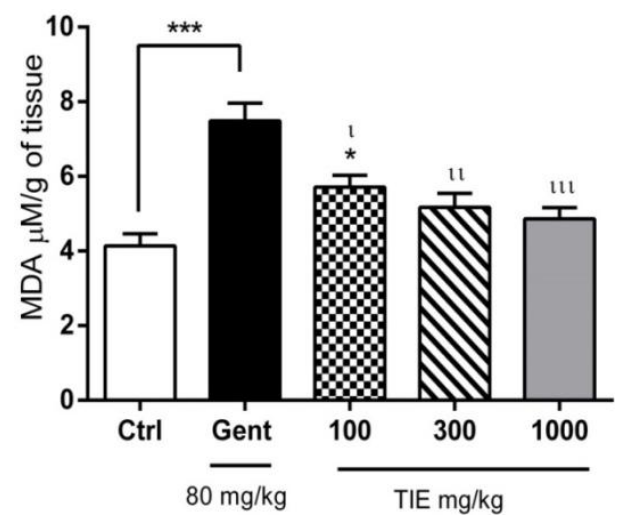

Fig. 4:Effect of Gentamicin $(80 \mathrm{mg} / \mathrm{kg})$ and TIE $(100,300,1000$ $\mathrm{mg} / \mathrm{kg}$ ) on MDA levels. $* \mathrm{p}<0.05$ and $* * * \mathrm{p}<0.001$ as compared to the control group (one way ANOVA followed by Sidak's post hoc test). ${ }^{t} p<0.05$, ${ }^{t t} p<0.01$ and ${ }^{t t t} p<0.001$ when compared to gentamicin group (one way ANOVA followed by Sidak's post hoc test).
Effect of TIE and Gentamicin on myeloperoxidase (MPO) levels

A significant increase $(\mathrm{p}<0.001)$ in tissue MPO levels was found in gentamicin-only treated groups compared to the control group. Rats treated with extract (300 and $1000 \mathrm{mg} / \mathrm{kg}$ ) significantly $(\mathrm{p}<0.01)$ showed decreased MPO formation when compared to the gentamicin-only group (Figure 5).

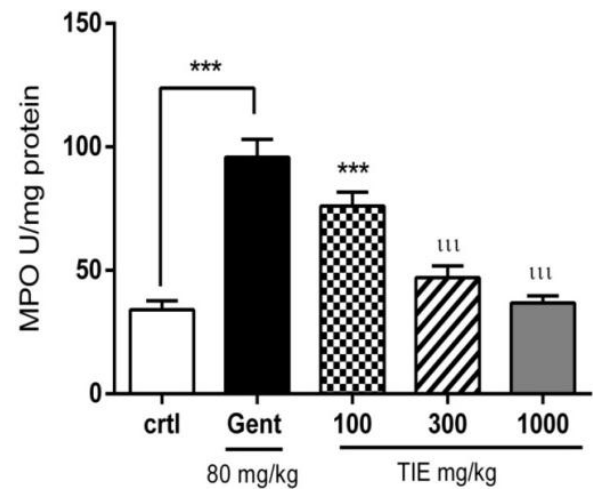

Fig. 5: Effect of gentamicin $(80 \mathrm{mg} / \mathrm{kg})$ and TIE $(100,300,1000 \mathrm{mg} / \mathrm{kg})$ on MPO levels. $* * * p<0.001$ as compared to the control group (one way ANOVA followed by Sidak's post hoc test) and tttp $<0.001$ when compared to gentamicin group (one way ANOVA followed by Sidak's post hoc test).

\section{Photomicrographs of kidneys showing the effect of TIE on gentamicin-induced nephrotoxicity}

Assessment of histomorphology of the kidneys showed normal glomerular and tubular histology in the medulla and cortical regions in control group. Gentamicin evoked severe glomerular degeneration, vacuolization, tubular casts and necrosis. In contrast, rats that received the extract at $100 \mathrm{mg} / \mathrm{kgwith}$ gentamicin showed a moderate reversal of renal injury. Combination treatment of gentamicin and extract at 300 and 1000 $\mathrm{mg} / \mathrm{kg}$ improved the renal injury dose-dependently compared to the control group (Figure 6)

\section{Effect of TIE and Gentamicin on AST, ALT and GGT}

The effect of the extract on gentamicin-induced liver damage was also assessed. Expectedly, significant elevation in AST $(\mathrm{p}<0.05)$, ALT $(\mathrm{p}<0.01)$ and GGT $(\mathrm{p}<0.01)$ were observed in the gentamicin-only treated group compared to the control. The extract at $1000 \mathrm{mg} / \mathrm{kg}$ however, significantly $(\mathrm{p}<0.05)$ reversed the AST, ALT and the GGT levels compared to the gentamicin group. The extract at $300 \mathrm{mg} / \mathrm{kg}$ reduced only the ALT significantly $(\mathrm{p}<0.05)$ but not AST or ALT (Table 3).

\section{Effect of TIE and Gentamicin on ALP, total bilirubin, and total protein levels}

Induction of liver damage with gentamicin, significantly ( $p<0.01)$ increased ALP when compared to the control. The extract at $1000 \mathrm{mg} / \mathrm{kg}$ significantly $(\mathrm{p}<0.05)$ reduced ALP when compared to the gentamicin group. Total bilirubin increased significantly $(\mathrm{p}<0.01)$ in the gentamicin-only treated group compared to the control. 


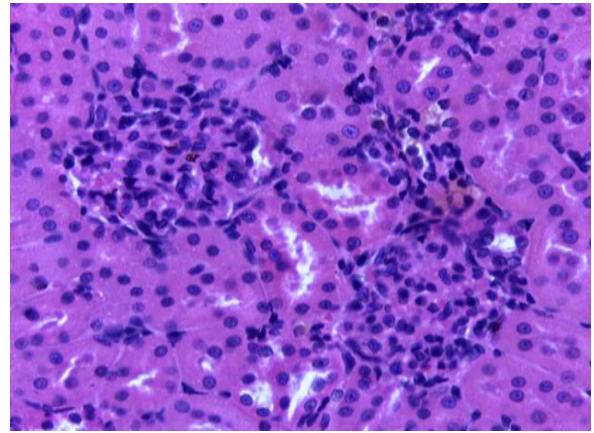

(A) Control

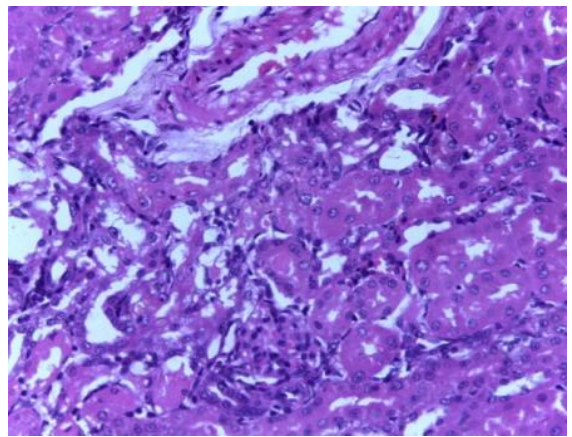

(B) Gentamicin $(80 \mathrm{mg} / \mathrm{kg})$

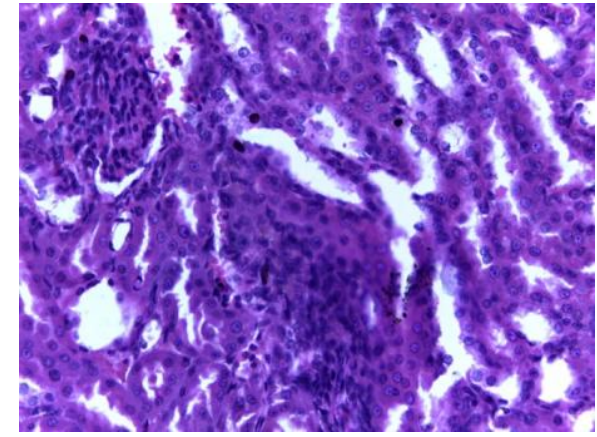

(C) $100 \mathrm{mg} / \mathrm{kg}$ TIE\&gentamicin $(80 \mathrm{mg} / \mathrm{kg})$

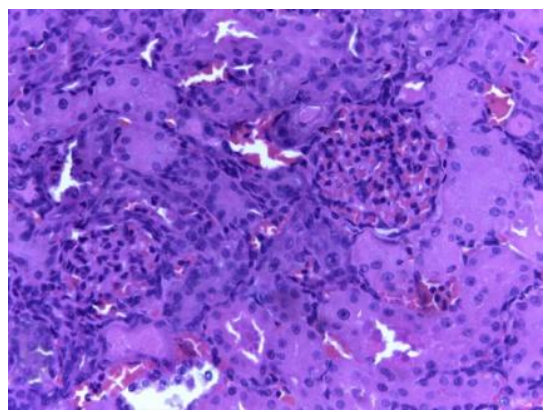

(D) $300 \mathrm{mg} / \mathrm{kg}$ TIE \& gentamicin $(80 \mathrm{mg} / \mathrm{kg})$

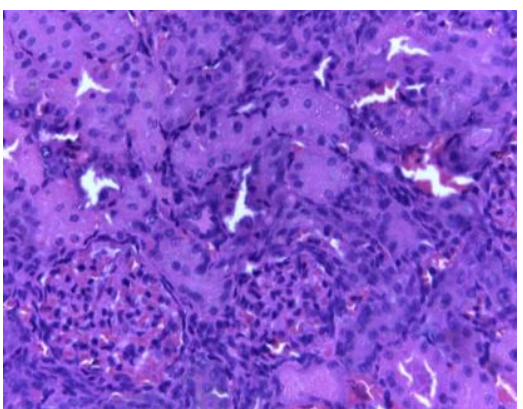

(E) $1000 \mathrm{mg} / \mathrm{kg}$ TIE \& gentamicin $(80 \mathrm{mg} / \mathrm{kg})$

Fig. 6: Effect of gentamicin $80 \mathrm{mg} / \mathrm{kg}$ and TIE $(100,300,1000 \mathrm{mg} / \mathrm{kg})$ on kidney histology.

Table 3: Effect of TIE and Gentamicin on AST, ALT and GGT levels.

\begin{tabular}{|c|c|c|c|}
\hline Treatment group & AST / U/L & ALT/ U/L & GGT / U/L \\
\hline Control: distilled $10 \mathrm{ml} / \mathrm{kg}$ & $298.8 \pm 4.9$ & $116.2 \pm 13.1$ & $1.6 \pm 0.12$ \\
\hline Gent $80 \mathrm{mg} / \mathrm{kg}$ & $985.5 \pm 270.5^{*}$ & $218.8 \pm 29.6^{* *}$ & $4.6 \pm 0.77 * *$ \\
\hline TIE $100 \mathrm{mg} / \mathrm{kg}$ + Gent $80 \mathrm{mg} / \mathrm{kg}$ & $709.0 \pm 145.5$ & $142.8 \pm 15.6$ & $3.8 \pm 0.73$ \\
\hline TIE $300 \mathrm{mg} / \mathrm{kg}$ + Gent $80 \mathrm{mg} / \mathrm{kg}$ & $447.4 \pm 38.9$ & $122.2 \pm 15.9^{\mathrm{t}}$ & $2.8 \pm 0.46$ \\
\hline TIE $1000 \mathrm{mg} / \mathrm{kg}+$ Gent $80 \mathrm{mg} / \mathrm{kg}$ & $361.2 \pm 26.8^{\mathrm{t}}$ & $126.2 \pm 4.3^{\mathrm{t}}$ & $2.0 \pm 0.17^{\mathrm{t}}$ \\
\hline
\end{tabular}

All data are expressed as mean \pm S.E.M. $(\mathrm{n}=6),{ }^{*} \mathrm{p}<0.05$ and ${ }^{* *} \mathrm{p}<0.01$ as compared to control group. ${ }^{\mathrm{t}} \mathrm{p}<0.05$ and ${ }^{\text {tt}} \mathrm{p}<0.01$ as compared to gentamicin group (one way ANOVA followed by Sidak's post hoc test).

Table 4: Effect of TIE and Gentamicin on ALP, total bilirubin, and total protein levels.

\begin{tabular}{llll}
\hline Treatment group & ALP/ $/ \mathbf{L}$ & Total bilirubin/ $\boldsymbol{\mu m o l} / \mathbf{L}$ & Total protein $/ \mathbf{g} / \mathbf{L}$ \\
\hline Control: distilled $10 \mathrm{ml} / \mathrm{kg}$ & $176.9 \pm 23.7$ & $4.2 \pm 0.49$ & $71.0 \pm 0.81$ \\
Gent $80 \mathrm{mg} / \mathrm{kg}$ & $296.7 \pm 15.5^{* *}$ & $6.3 \pm 0.49^{* *}$ & $56.3 \pm 2.63^{* * *}$ \\
TIE $100 \mathrm{mg} / \mathrm{kg}+$ Gent $80 \mathrm{mg} / \mathrm{kg}$ & $228.4 \pm 13.2$ & $4.9 \pm 0.16$ & $61.6 \pm 2.65^{*}$ \\
TIE $300 \mathrm{mg} / \mathrm{kg}$ + Gent $80 \mathrm{mg} / \mathrm{kg}$ & $224.9 \pm 32.2$ & $4.6 \pm 0.19^{\mathrm{t}}$ & $61.2 \pm 1.14^{*}$ \\
TIE $1000 \mathrm{mg} / \mathrm{kg}+$ Gent $80 \mathrm{mg} / \mathrm{kg}$ & $189.6 \pm 14.3^{\mathrm{t}}$ & $4.2 \pm 0.25^{\mathrm{tt}}$ & $66.3 \pm 1.34^{\mathrm{tt}}$ \\
\hline All
\end{tabular}

All data are expressed as mean \pm S.E.M. $(\mathrm{n}=6),{ }^{*} \mathrm{p}<0.05$, ${ }^{* *} \mathrm{p}<0.01$ and ${ }^{* * *} \mathrm{p}<0.001$ as compared to control group. ${ }^{\mathrm{t}} \mathrm{p}<0.05$ and ${ }^{\mathrm{tt}} \mathrm{p}<0.01$ as compared to gentamicin group (one way ANOVA followed by Sidak's post hoc test).

The extract however, significantly reduced total bilirubin dose-dependently at $300(\mathrm{p}<0.05)$ and $1000 \mathrm{mg} / \mathrm{kg}(\mathrm{p}<0.01)$ compared to the gentamicin group. Total protein also showed a significant decrease in the gentamicin-only group ( $\mathrm{p}<0.001)$. The extract increased the total protein significantly $(\mathrm{p}<0.05)$ at $100 \mathrm{mg} / \mathrm{kg}$ and $300 \mathrm{mg} / \mathrm{kg}$ compared to the control group. At 1000 $\mathrm{mg} / \mathrm{kg}$ of extract total protein levels increased significantly $(\mathrm{p}<$ 0.01) compared to the gentamicin group (Table 4).

\section{Effect of TIE and Gentamicin on globulin and albumin levels}

Globulin levels were significantly low $(p<0.01)$ in the gentamicin-only group when compared to the control group. The extract at 300 and $1000 \mathrm{mg} / \mathrm{kg}$ significantly increased $(\mathrm{p}<0.05)$ globulin levels ascompared to the gentamicin group. Albumin levels were also decreased in gentamicin $(p<0.001)$ and $p<0.05$ (100 and $300 \mathrm{mg} / \mathrm{kg}$ of extract) as compared to the control group. Extract at $1000 \mathrm{mg} / \mathrm{kg}$ however significantly elevated $(\mathrm{p}<0.05)$ albumin levels as compared to the gentamicin group (Table 5).

\section{Photomicrographs of rat liver showing the effect of TIE on gentamicin-induced hepatic damage}

Assessment of liver histology showed normal liver histology in the control group. The gentamicin group showed congested hepatic sinusoids and blood vessels, apoptotic cells, severe vacuolization and necrosis. The extract at all doses showed improved the liver architecture with no visible lesions similar to the control group (Figure 7). The observations on the photomicrographs correlated well with the biochemical findings. 


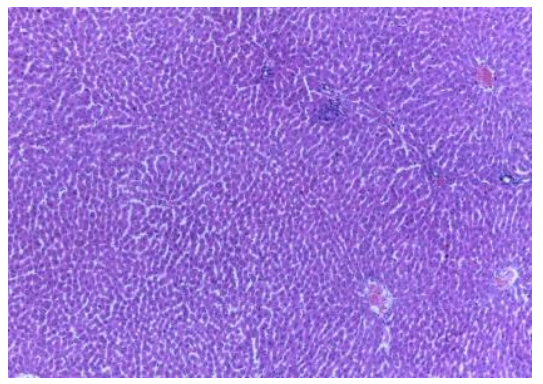

(A)Control

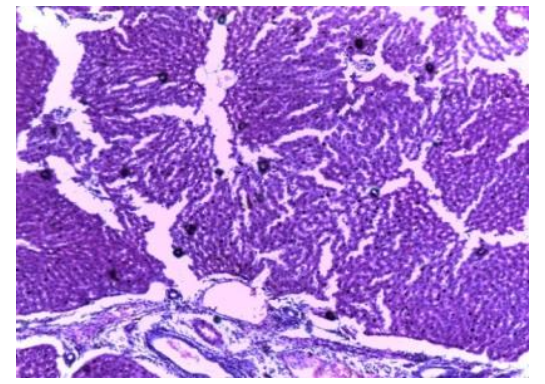

(B) Gentamicin $(80 \mathrm{mg} / \mathrm{kg})$

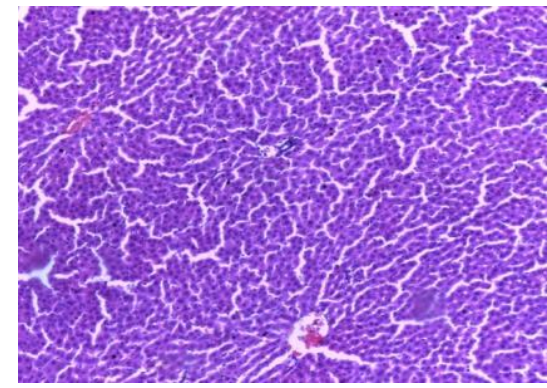

(C) $100 \mathrm{mg} / \mathrm{kg}$ TIE\& gentamicin $(80 \mathrm{mg} / \mathrm{kg})$

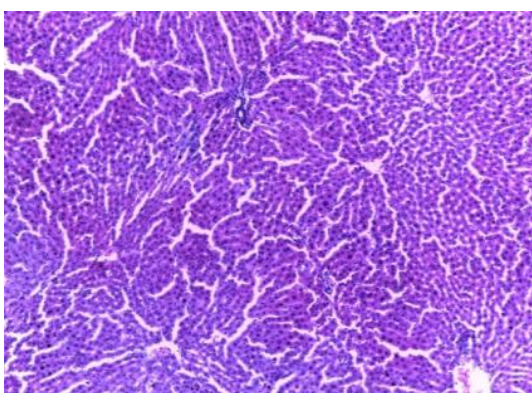

(D) $300 \mathrm{mg} / \mathrm{kgTIE} \&$ gentamicin $(80 \mathrm{mg} / \mathrm{kg})$

(A)

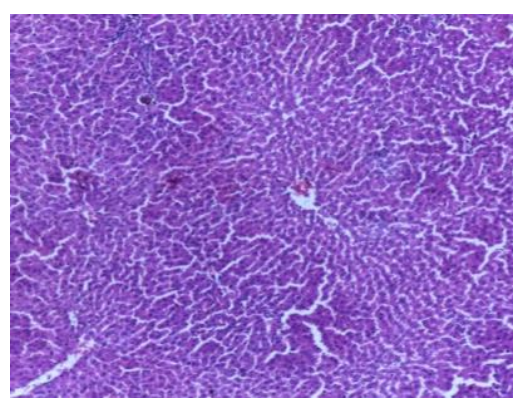

(E) $1000 \mathrm{mg} / \mathrm{kg}$ TIE\& gentamicin $(80 \mathrm{mg} / \mathrm{kg})$

Fig. 7: Effect of gentamicin $80 \mathrm{mg} / \mathrm{kg}$ and TIE $(100,300,1000 \mathrm{mg} / \mathrm{kg})$ on liver histology.

Table 5: Effect of TIE and Gentamicin on globulin and albumin levels

\begin{tabular}{lll}
\hline Treatment group & Globulin $/$ g/L & Albumin $/$ g/L \\
\hline Control: distilled $10 \mathrm{ml} / \mathrm{kg}$ & $25.5 \pm 0.62$ & $44.3 \pm 0.94$ \\
Gent $80 \mathrm{mg} / \mathrm{kg}$ & $19.8 \pm 0.82^{* *}$ & $37.7 \pm 0.71^{* * *}$ \\
TIE $100 \mathrm{mg} / \mathrm{kg}+$ Gent $80 \mathrm{mg} / \mathrm{kg}$ & $22.6 \pm 0.86$ & $39.7 \pm 0.54^{*}$ \\
TIE $300 \mathrm{mg} / \mathrm{kg}+$ Gent $80 \mathrm{mg} / \mathrm{kg}$ & $24.5 \pm 1.40^{\mathrm{t}}$ & $40.3 \pm 1.45^{*}$ \\
TIE $1000 \mathrm{mg} / \mathrm{kg}+$ Gent $80 \mathrm{mg} / \mathrm{kg}$ & $24.1 \pm 0.88^{\mathrm{t}}$ & $41.8 \pm 0.47^{\mathrm{t}}$ \\
\hline All
\end{tabular}

All data are expressed as mean \pm S.E.M. $(\mathrm{n}=6), * \mathrm{p}<0.05, * * \mathrm{p}<0.01$ and $* * * \mathrm{p}<0.001$ as compared to control group. ${ }^{\mathrm{t}} \mathrm{p}<0.05$ as compared to gentamicin group (one way ANOVA followed by Sidak's post hoc test).

\section{DISCUSSION}

Medicinal plants play a crucial role as the first line treatment for various diseases especially in the West Africa subregion due to their low cost, easy accessibility and minimal side effects (Annan et al., 2012; Gopalakrishnan and Dhanapal, 2014). In spite of the wide use of these plants for the cure of many diseases, the safety or potential toxicity of many of these plants has not been scientifically investigated (Ansah et al., 2009).

Among the plants used by herbalists include Terminalia ivorensis, which is used for ulcers, wounds, diuresis, general body pains, malaria, hemorrhoids and yellow fever (Burkill, 1985; Etukudo, 2003; Akinyemi et al., 2006; Quattara et al., 2013). It is also used as timber, anti-cough, anti-hyperglycemic, anti-parasitic anti-inflammatory and anti-arthritis as well as for skin and oral infections (Iwu and Anyanwu, 1982; Agbedahunsi, 2006; Johnny et al., 2014).

However, very little is known about its effect on nephrotoxic and hepatotoxic effects induced by gentamicin. The present study examined the possible nephroprotective and hepatoprotective effects of Terminalia ivorensis ethanolic stem bark extract against gentamicin-induced toxicity in SpragueDawley rats. Nephrotoxicity is an adverse effect of chemotherapy (Chatterjee et al., 2012). Drug or chemical induced nephrotoxicity depends on their build-up in renal cortex, affinity to kidneys and the kinetics of drug trapping process (Noorani et al., 2010). Gentamicin is a commonly used aminoglycoside for the cure of life threatening gram-negative infections. It usually accumulates in the renal proximal tubules and enhances hydrogen peroxide generation by the mitochondria (Noorani et al., 2010). The hydrogen peroxide produced causes the release of iron from mitochondria membranes which complexes with gentamicin to evoke the generation of reactive oxygen species (Afeefa et al., 2012). This antibiotic has been shown to dose-dependently induce nephrotoxicity when administered for more than 7-10 days (Noorani et al., 2010; Geevasinga et al., 2006).

Gentamicin at $80 \mathrm{mg} / \mathrm{kg}$ body weight administered intraperitoneally for two consecutive weeks in rats is known to cause significant nephrotoxicity (Qadir et al., 2011; Chatterjee et al., 2012). In this study, gentamicin ( $80 \mathrm{mg} / \mathrm{kg}$ administered for 14 days), induced renal dysfunction which was evidenced by significant increase in serum urea, creatinine and electrolytes with obvious histological injury.

The elevated levels of serum markers were significantly reduced in extract pretreated groups (300 and $1000 \mathrm{mg} / \mathrm{kg}$ ) when compared to the gentamicin treated groups. The reduction in the renal markers (creatinine and urea) and serum electrolytes (sodium, potassium and chloride) demonstrated that the extract 
minimized cell damage caused by gentamicin thereby improving renal function. In several animal models, oxidative stress has been strongly linked to nephrotoxicity and hepatotoxicity. During toxicity, there is a build-up of reactive species, which results in an oxidative degradation of lipids, proteins and DNA (Girotti, 1998). Exposure of an organism to gentamicin causes a build-up of oxidative stress in the system (Chatterjee et al., 2012, Gowrisri et al., 2012), which is evidenced by diminished levels of GSH, SOD and catalase as well as increase in lipid peroxidation and cellular damage (Gowrisri et al., 2012)

In this study, as expected, gentamicin significantly decreased SOD, GSH and catalase levels and caused an increasein lipid peroxidation, myeloperoxidase and tissue damage. Extract pretreated animals showed significantly elevated superoxide dismutase (SOD), reduced glutathione (GSH) and catalase levels as compared to the gentamicin group. The formation of myeloperoxidase and the lipid peroxidation product (MDA) were also observed to be significantly reduced when compared to the gentamicin-only treated group. The activity shown by Terminalia ivorensis ethanolic stem bark extract might be due to its ability to induce antioxidant enzymes as observed in the present study.

Kidney sections of the control rats showed normal architecture of tubules while the gentamicin group showed severe glomerular degeneration, vacuolization, tubular casts and necrosis. However, pretreatment of rats with extract at $100 \mathrm{mg} / \mathrm{kg}$ showed a moderate reduction of kidney features of injury. Again, pretreatment of rats with extract at 300 and $1000 \mathrm{mg} / \mathrm{kg}$ showed further decrease in renal injury similar to control group. Pretreatment of rats with extract therefore offered a protective effect against renal damage caused by gentamicin.

Gentamicin has also been shown to induce hepatotoxicity secondary to nephrotoxicity and ototoxicity. It induces hepatic injury by promoting the generation of free radicals which attack and destroy hepatocytes (Noorani et al., 2010; Al-Kenanny et al., 2012). Drug - induced hepatotoxicity is characterized by elevated levels of ALT, AST, ALP, GGT and bilirubin as well as destruction of tissue histology (Kurtovic and Riordan, 2003; Sivakrishnan and Kottaimuthu, 2013; Adejuwon et al., 2014).

High levels of these enzymes are consequences of hepatocytes destruction and increase in cellular permeability (Sivakrishnan and Kottaimuthu, 2013), whereas increased amount of bilirubin is indicative of loss of functional efficiency of hepatic cells in binding, conjugating and excreting bilirubin (Saroswat et al., 1993; Singh et al., 2005).

In this study, gentamicin showed significant increase in the levels of liver biomarkers (ALT, AST, ALP, GGT and bilirubin) and decrease levels of total proteins, globulin and albumin as well as cause severe liver destruction. However, coadministration of extract and gentamicin significantly normalized the levels of these markers and restored liver structure. This finding correlates with previous reports by Noorani et al., (2010) and Al-Kenannay et al., (2012), who also showed that gentamicin induces hepatotoxicity evidenced by elevated levels of serum enzymes. Ethanolic stem bark extract of Terminalia ivorensis significantly reduced the damage caused by gentamicin probably through a protective effect against cellular destruction and restoration of hepatocytes integrity.

\section{CONCLUSION}

Terminalia ivorensis has nephroprotective and hepatoprotective effects against gentamicin-induced toxicity by enhancing kidney and liver functions evidenced by reversal in the alteration of renal and hepatic markers of cellular damage and restoration of cellular structure. The mechanism of the nephroprotection and hepatoprotection of $T$. ivorensisis proposed to be by the enhancement of the activities of antioxidants.

\section{ACKNOWLEDGEMENTS}

We are grateful to the technical staff of the Department of Pharmacology and KNUST Central lab especially Mr. Thomas Ansah, Dr. Edmund Ekuadze and Mr. Edmund Dery for their support.

\section{REFERENCES}

Aashish P, Tarun S and Pallavi B. Drug-Induced hepatotoxicity: A Review. J. Appl. Pharm. Sci, 2012; 2: 233-243.

Adejuwon AS, Femi-Akinlosotu O, Omirinde JO,Owolabi OR and Afodum AM. Launaea taraxacifolia Ameliorates Cisplatin - induced Hepato - renal injury. Eur. J. of Med. Plants, 2014; 4: 528 - 541.

Afeefa T, Uzma S, Saeed M, Furqan KH, Khalid H, Nadeem IB and Bashir A. Evaluation of protective and curative role of $\alpha$-lipoic acid and selenium in gentamicin induced nephrotoxicity in rabbits. Pak. J. Pharm. Sci, 2012; 25: 103 - 10.

Agbedahunsi JM, Anao I, AdewunmiCO and Croft SL. Trypanocidal properties of Terminalia ivorensis A. Chev. (Combretaceae). Afr. J. Trad. CAM, 2006; 3: 51-56.

Akinyemi KO, Oluwa OK and Omomigbehin EO. Antimicrobial activity of crude extracts of three medicinal plants used in South-West Nigerian folk medicine on some food borne bacterial pathogens. Afr. J. Trad. CAM, 2006; 3: 13 - 22.

Al-Kenanny ER, Al-HayalyLK and Al-Badrany AG. Protective Effect of Arabic Gum on liver Injury Experimentally Induced by Gentamicin in Mice. Kufa J. Vet. Med. Sci, 2012;3: 174 - 189.

Annan K, Sarpong K, Asare C, Dickson R, Amponsah IK, Gyan $\mathrm{B}$, Ofori $\mathrm{M}$ and Gbedema SY. In vitro anti-plasmodial activity of three herbal remedies for malaria in Ghana: Adenia cissampeloides (Planch.) Harms., Termina ivorensis A. Chev, and Elaeis guineensis Jacq. Pharmacog. Res, 2012; 4: 225-229.

Ansah C, Oppong E, Woode E and Duwiejua M. Toxicity studies on Alchornea cordifolia leaf Extract in mice. J. Sci. Tech, 2009; 29: $8-16$.

Aslam M, Dayal R, Javed R, Parray SA, Jetley S and Samim M. Nephroprotective Effects of Peucedanum grande against Acute Renal Failure Induced by Potassium dichromate in Rats. Int. J. Pharm. Sci. Drug Res, 2013; 5: 45-49.

Burkill HM. The Useful Plants of West Africa. Royal Botanical Gardens: Kew, 1985; 1: $960-976$.

Chatterjee P, Mukherjee A and Nandy S. Protective effects of the aqueous leaf extract of Aloe barbadensison gentamicin and cisplatininduced nephrotoxic rats. Asian Pac. J. Trop. Biomed, 2012; S1754 S1763.

Conlon BJ, Aran JM and Erre JP. Attenuation of aminoglycoside induced cochlear damage with the metabolic antioxidant alphalipoic acid. Hear Res, 1999; 128: 40-44. 
Coresh J, Selvin E, Stevens LA, Manzi J, Kusek JW, Eggers P and Levey AS.Prevalence of chronic kidney disease in the United States. JAMA, 2007; 298: 2038-2047. 1959; 82: $70-77$.

Ellman GL. Tissue sulfhydryl groups. Arch Biochem Biophys,

Eslami SH, Ebrahimzadeh MA, Moghaddam HA, Nabavi SF, Jafari N and Nabavi SM. Renoprotective effect of Eryngium caucasicum in gentamicin-induced nephrotoxic mice. Arch. BiolSci, 2011; 63:157-160.

Etukudo I. 2003. Ethnobotany: Conventional and Traditional Uses of plants. The Verdicts Press, Uyo. p 41.

Geevasinga N, Coleman PL, Webster AC and Roger SD. 2006. Proton pump inhibitors and acute interstitial nephritis. Clin. Gastroenterol. Hepatol, 2006; 4: 597-604.

Girotti AW. Lipid hydroperoxide generation, turnover, and effector action in biological systems. J. Lip. Res, 1998;39: 1529 - 1542.

Gopalakrishnan G and Dhanapal CK. Evaluation of in-vivo antioxidant Activity of Methanolic Extract of Coleus Vettiveroides Jacob. In Streptozotocin-induced Oxidative Stress in Rats. Int. J. Pharm. Pharm. Sci, 2014; 6: $590-592$.

Gowrisri M, Vikram KS, Sarita K, Vrushabendra SBM, Archana SP and Vishwanath KM. Anti-oxidant and Nephroprotective Activities of Cassia occidentalis Leaf Extract against Gentamicin Induced Nephrotoxicity in Rats. Res. J. Pharm. Biol. Chem. Sci, 2012; 3: $684-$ 694.

Iwu MM and Anyanwu BN. Phytotherapeutic profile of Nigerian herbs, Antiinflammatory and anti-arthritic agents. $J$ Ethnopharmacol, 1982; 6: 263-274.

Jaeschke H, Gores GJ, Cederbaum AI, Hinson JA, Pessayre D and Lemasters JJ. Mechanisms of hepatotoxicity. Toxicol Sci, 2002; 65: 166-176.

Johnny II, Ekong NJ and Okon JE. Phytochemical Screening and Antihyperglycaemic Activity of Ethanolic Extract of Terminalia ivorensis A. Chev. Leaves on Albino Wistar Rats. Global Adv. Res. J. Med. Med. Sci, 2014; 3: 186-189.

KurtovicJ and Riordan SM. Paracetamol induced hepatotoxicity at recommended Dosage. J. Int. Med, 2003;253: 240-243.

Leehey DJ, Braun BI and Tholi DA. Can pharmacokinetic dosing decrease nephrotoxicity associated with aminoglycoside therapy? $J$ Am Soc Nephrol, 1993; 4: 81-90.

Luft FC and Kleit SA. Renal parenchymal accumulation of aminoglycoside antibiotics in rats. J Infect Dis, 1974; 130:656 -659

Martines G, Butturini L and Menozzi I. Amikacin- induced liver toxicity: correlations between biochemical indexes and ultrastructural features in an experimental model. Rev. Med. Univ. Navarra, 1988; 32: $41-45$

Noorani AA, Gupta K, BhadadaK and Kale MK. Protective Effect of Methanolic Leaf Extract of Caesalpinia bonduc (L.) on Gentamicin-Induced Hepatotoxicity and Nephrotoxicity in Rats. Iran. J. Pharmacol. \& Ther, 2010;10:21 - 25 .
Ohkawa $\mathrm{H}$, Ohishi $\mathrm{N}$ and Yagi K. Assay for lipid peroxides in animal tissues by thiobarbituric acid reaction. Anal Biochem, 1979; 95: $351-358$.

Pedraza CJ, Maldonado PD and Medina CO. Garlic ameriolates gentamicin nephrotoxicity : relation to antioxidant enzymes. Free Radic Biol Med, 2000; 29 : 602-611.

Pedraza-Chaverri J, Yam-Canul P, Chirino YI, SánchezGonzález DJ, Martínez-Martínez CM, Cruz C and Medina-Campos ON. (2008). Protective effects of garlic powder against potassium dichromateinduced oxidative stress and nephrotoxicity. Food Chem. Toxicol, 2008; 46: 619-627.

Ouattara S, Kporou KE, Kra KAM, Zirihi GN, N'guessan JD, Coulibaly A and Djaman AJ.Antifungal activities of Terminalia ivorensis A. Chev.bark extracts against Candida albicans and Aspergillus fumigatus. J. Intercult Ethnopharmacol, 2013; 2: 49 - 52.

Qadir MI, Tahir M, Lone KP, Munir Band Sami W. Protective role of ginseng against gentamicin induced changes in kidney of albino mice. J Ayub Med Coll Abbottabad, 2011; 23: 53 - 57.

Rajitha P, Joyamma V and Dinoop DR. 2013. Are statins nephroprotective? A Dose in Albino rats.Int. J. Pharm. Pharm Sci, 2013; 5: $182-190$

Saroswat B, Visen PK, Patnalik GK and Dhawan BN. Anticholestic effect of picroliv, active hepatoprotective principle of Picrorhizza kurrooa against carbon tetrachloride induced cholestasis. Ind J. ExpBiol, 1993; 31: 316 - 318

Senoglu M, Kurutas EB, Altun I, Atli Yand Nacitarhan V. Myeloperoxidase Activities in Polymorphonuclear Leukocytes in Lumbar Disc Disease. J. Neurol. Sci. [Turk], 2009; 26: 292 - 297.

Singh B, Chandan BK, Prabhakar A, Taneja J, Singh H and Qazi N. Chemistry and hepatoprotective activity of an active fraction from Barteriaprionitis inn in experimental animals. Phytother Res, 2005; 19 : $391-404$.

Sinha AK. Colorimetric assay of catalase. Anal. Biochem, 1972;47: $389-394$

Sivakrishnan S and Kottaimuthu A. Hepatoprotective Activity of Ethanolic Extract of Aerial Parts of Albizia procera Roxb (Benth.) Against Paracetamol Induced Liver Toxicity on WistarRats. Int. J. Pharm. Pharm. Sci, 2013;6: 233 - 238 .

Sun Y, Oberley L and Li Y.A simple method for clinical assay of superoxide dismutase. Clin Chem, 1988; 34: 497 - 500.

\section{How to cite this article:}

Ansah C, Moomin A, Boadu KM. Terminalia Ivorensis A. Chev. Ethanolic Stem Bark Extract Protects Against Gentamicin Induced Renal and Hepatic Damage In Rats. J App Pharm Sci, 2016; 6 (04): 175-182. 